\title{
New beginnings: getting the kick I needed
}

\section{Kai Simons}

I come from the north, from the periphery of Europe - Finland. I studied medicine in Helsinki, but actually I wanted to do research and first I tried clinical research. A classical area of Finnish medicine was vitamin $B_{12}$. Why? Because a large part of the Finnish population was infected with the broad tapeworm, a parasite that colonizes the intestine and needs vitamin $\mathrm{B}_{12}$ for growth. Some people infected with the tapeworm develop pernicious anaemia, which is why vitamin $B_{12}$ was an area for medical research.

I joined the Minerva Institute of Medical Research as a medical student and my first project was to measure absorption of vitamin $B_{12}$ from a patient's gut. I had to position a tube with two inflatable balloons in the ileum and repeatedly X-ray the patient to ensure that I had found the right location. My patient was an old lady and she was embarrassingly grateful to me because I spent so much time with her - little did she realize that it was because of my inability to position the tube correctly. This was my attempt at clinical research.

For my PhD thesis, I instead purified and characterized intrinsic factor, the protein secreted in gastric juice required for vitamin $\mathrm{B}_{12}$ absorption. We had to collect $30 \mathrm{l}$ (!) of human gastric juice before we could start the purification. To collect this volume of gastric juice, my supervisor, Ralph Gräsbeck, hired a beautiful nurse who toured the prisons of Helsinki and the line of volunteers steadily grew. When she intubated me I suffered laryngeal spasm (because I have such a sensitive throat) and almost choked to death. Having survived, we successfully purified the protein for the first time.

Kai Simons is Research Group Leader and Director Emeritus at the Max-Planck-Institute of Molecular Cell Biology and Genetics, Dresden 0130, Germany. e-mail: simons@mpi-cbg.de
At that time, in the 1960s, we had few international contacts in Helsinki and I had difficulty in finding a lab where I could do postdoctoral work. I saw a paper by Alexander Bearn from the Rockefeller University, on Wilson's disease, a condition characterized by excessive deposition of copper in all tissues, caused by increased absorption of copper from the small intestine. Somehow, a serum protein called ceruloplasmin was involved. I joined Bearn's lab only to find out that they no longer worked on this topic. Instead, serum protein polymorphisms were on the agenda.

I continued to expand my knowledge of protein chemistry by purifying and characterizing serum proteins. But most importantly, I met a Finnish virologist, Leevi Kääriäinen, who worked in the neighbouring Sloan-Kettering Institute. He told me about his virus, the Semliki Forest virus. I can still vividly remember him telling me about the virus membrane and how the virus is enveloped by a piece of the host cell plasma membrane. During this process, only the virus spike glycoprotein is incorporated and the host proteins are excluded. SDS gel electrophoresis, which had recently been developed, showed that the Semliki Forest virus had only two bands: one from the nucleocapsids and another from the viral envelope. So, it was the simplest membrane in the world!

Leevi then returned to Helsinki and later, I too went back. We had both joined the Haartman Institute, and were working in a new building of the Medical Faculty. I continued my work on serum protein polymorphisms but, the planned collaboration with Leevi on the Semliki Forest virus was slow in getting started. Unexpectedly, a visit to the Laboratory of Molecular Biology (LMB) in Cambridge led to an important turning point. I had a Swedish friend who worked with Brian Hartley, a famous protein chemist at the LMB. Brian spent quite some time with me during my short visit. I told him about my work in trying to purify Gc protein variants and to find out how these variants differ at the molecular level. I recall how Brian not so gently asked me, "Kai, do you really think this work is interesting?" Deep inside me I knew this work was boring but I needed this kick from Brian. "Don't you have another more interesting project that you would want to tackle?" Then, I told him about the Semliki Forest virus membrane and in a split second he convinced me that this was the project to pursue.

My encounter with Brian Hartley showed me that you have to ask ambitious questions if you want to get ahead in your research. I had not been taught this before. You also have to find an interesting problem to work on. The choice of system is key to success. Many scientists continue to work on the questions that they studied during their predoctoral and postdoctoral periods. Real advances can often come from moving sideways and working in new areas that have not been pursued before. Nature is full of fascinating problems, accessible to those who have the courage to think outside the box. When I went back to Helsinki, I told my small group that we would now focus on membranes and that we should take up the Semliki Forest virus as our experimental system. We formed a troika with Leevi Kääriäinen and with Ossi Renkonen, a lipid chemist, to work on this problem together.

In my own group I had the privilege of working with two outstanding graduate students: Ari Helenius and Henrik Garoff. With the Semliki Forest virus in our bags, we three formed a second troika and soon took off to the recently founded European Molecular Biology Laboratory in Heidelberg. There, we unravelled how the Semliki Forest virus gets in and out of the cell.

COMPETING FINANCIAL INTERESTS

The author declares no competing financial interests. 